\title{
The efficiency of using different fertilization systems in dryland and irrigated crop rotations on ordinary carbonate chernozems of the Central Ciscaucasia
}

\author{
Tamara Bizhoeva, Ruslan Bizhoev*, Asiyat Sarbasheva, Olga Batyrova, and Aslanbek \\ Kushkhabiev \\ Institute of Agriculture - Branch of the Kabardino-Balkarian Scientific Center of the Russian \\ Academy of Sciences, 224, Kirova Street, 360004 Nalchik, Kabardino-Balkarian Republic
}

\begin{abstract}
The search for the rational use of fertile irrigated land in the steppe zone of Central Ciscaucasia and the determination of factors for the sustainable production of crop products, provided that soil fertility is maintained, remained as valid today as ever. The relevance of research is also increasing due to changes in climatic characteristics in specific agrolandscape conditions, including, an increase in average daily and annual air temperatures by $2-50 \mathrm{C}$. The novelty of research is the establishment of the most efficient fertilization systems in dryland and irrigated conditions to increase winter wheat yields, to increase the productivity of 1 ha of crop area, as well as to maintain and reproduce soil fertility and to increase the productivity of irrigated crop rotation. The article contains the research results on the use of different fertilization systems and their influence on winter wheat yields and crop rotation productivity in dryland and irrigated agriculture on ordinary carbonate chernozems in specific agro-landscape, soil and climatic characteristics of the Central Ciscaucasia.
\end{abstract}

\section{Introduction}

Intensive use of arable land and accelerated mineralization of organic matter, together with a sharp decrease in the use of organic and mineral fertilizers, irrational use of irrigation water and an insufficient share of perennial grasses in crop rotation leads to a general decline in soil fertility and, as a result, a decline in crop yields and crop rotation efficiency [1]. In this regard, farming systems are focused on evidence-based crop rotation systems that reduce production costs, improve soil fertility, regulate the food, water and air regimes of the soil, without requiring additional material costs, which is very important for producing environmentally friendly crop products and reducing their cost [2].

\footnotetext{
${ }^{*}$ Corresponding author: kbniish2007@yandex.ru
} 


\section{Materials and methods}

Scientific research was carried out in a long-term stationary field experiment, located on the experimental field of the Institute of Agriculture of the Kabardino-Balkarian Scientific Center of the Russian Academy of Sciences in the village Krasnoarmeyskoye, Tersk region, Kabardino-Balkarian Republic, founded in 1948 by P. E. Prostokov, professor of the Department of Agrochemistry, North Ossetian Agricultural Institute. From the moment of setting up to the present time, the fertility of the ordinary carbonate chernozem is monitored in the experiment with long-term irrigation and systematic use of fertilizers in the agricultural landscape system of agriculture. The research is coordinated by the Geographical Network of Experiments with Fertilizers and Other Agrochemicals in the Russian Federation, the experiment is included in the Register of Long-term Experiments and registered under No. 037, and is conducted according to classical methods. R\&D reports are annually submitted to the Geographic Network, which maintains an information database of long-term stationary experiments for more than 70 years at the federal level.

This article presents the results of research on winter wheat. Experiment scheme: alternation of 4 crops in a crop rotation - winter wheat, maize, sunflower and alfalfa for 1 and 2 years of use with different mineral and organo-mineral fertilizers. Estimated mineral and organo-mineral fertilization systems are designed to preserve and reproduce soil fertility and to increase the productivity of irrigated crop rotation.

The number of options in the experiment is 100 , the number of plots is 200 . The site area is $165.6 \mathrm{~m}^{2}$, with a site width of $6.9 \mathrm{~m}$ and a length of $24.0 \mathrm{~m}$; the accounting area of the site varies from 33.6 to $73.2 \mathrm{~m}^{2}$, depending on the culture and method of accounting.

Fertilizers were manually applied according to the experiment scheme in autumn for the main plowing. The following forms of fertilizer were used: ammonium nitrate, simple and double super phosphate, potassium salt, semi-superior manure. In recent years, ammonium nitrate, ammonium phosphate and nitro-ammonium phosphate were used because of the lack of required fertilizers such as super phosphate and potassium fertilizers and their cost.

Yield data from the experiment are reduced to $14 \%$ (maize grain, winter wheat, peas), $16 \%$ (alfalfa hay) and 12\% (sunflower seeds) of standard humidity.

The prevailing climatic characteristics of the studied growing seasons are presented in Table 1.

The studies were performed in accordance with the guidelines for conducting research in long-term experiments with fertilizers [3.4.5], field experience methodology [6], agrochemical research technique [7] and methodological and organizational bases of conducting agroecological monitoring in intensive agriculture [8]. The methodology of the All-Russian Research Institute of Agrochemistry named after D.N. Pryanishnikov was used in selecting plant and soil samples. Agrochemical analyses of soil and plants were performed by standard methods, according to the GOST. The research results were statistically evaluated [6]. 
Table 1. Characteristics of the meteorological conditions of the crop growing seasons in 2017-2020.

\begin{tabular}{|c|c|c|c|c|c|c|c|}
\hline \multirow[t]{2}{*}{ Year } & \multirow[t]{2}{*}{ Month } & \multicolumn{2}{|c|}{ Air temperature, ${ }^{\circ} \mathrm{C}$} & \multicolumn{2}{|c|}{$\begin{array}{c}\text { Monthly } \\
\text { precipitation, } \mathbf{m m}\end{array}$} & \multicolumn{2}{|c|}{ Relative humidity, \% } \\
\hline & & current & $\begin{array}{c}\text { long-term } \\
\text { average } \\
\text { annual }\end{array}$ & current & $\begin{array}{c}\text { long-term } \\
\text { average } \\
\text { annual }\end{array}$ & current & $h$ average annual \\
\hline \multirow[t]{4}{*}{2017} & September & 20.7 & 17.3 & 13.7 & 36.1 & 63 & 74 \\
\hline & October & 11.1 & 10.5 & 41.2 & 30.1 & 75 & 82 \\
\hline & November & 4.9 & 3.9 & 23.6 & 23.5 & 86 & 88 \\
\hline & December & 2.1 & -0.9 & 40.7 & 21.0 & 90 & 90 \\
\hline \multirow[t]{9}{*}{2018} & January & -1.5 & -3.1 & 27.9 & 17.9 & 91 & 89 \\
\hline & February & 2.1 & -2.4 & 40.4 & 17.4 & 90 & 86 \\
\hline & March & 5.1 & 2.5 & 92.0 & 28.0 & 79 & 84 \\
\hline & April & 11.9 & 10.7 & 16.2 & 43.5 & 67 & 74 \\
\hline & May & 19.4 & 16.3 & 87.1 & 63.5 & 65 & 72 \\
\hline & June & 22.3 & 20.6 & 42.8 & 77.9 & 59 & 69 \\
\hline & July & 25.9 & 23.1 & 34.0 & 59.9 & 65 & 67 \\
\hline & August & 22.7 & 22.5 & 43.6 & 46.9 & 65 & 69 \\
\hline & September & 19.9 & 17.3 & 8.4 & 36.1 & 65 & 74 \\
\hline \multirow[t]{12}{*}{2019} & January & -0.1 & -3.1 & 13.1 & 17.9 & 84 & 89 \\
\hline & February & 1.9 & -2.4 & 8.6 & 17.4 & 83 & 86 \\
\hline & March & 6.6 & 2.5 & 36.4 & 28.0 & 70 & 84 \\
\hline & April & 11.1 & 10.7 & 50.4 & 43.5 & 67 & 74 \\
\hline & May & 18.8 & 16.3 & 72.6 & 63.5 & 70 & 72 \\
\hline & June & 25.9 & 20.6 & 28.9 & 77.9 & 60 & 69 \\
\hline & July & 24.9 & 17.3 & 39.0 & 36.1 & 67 & 74 \\
\hline & August & 24.9 & 10.5 & 26.9 & 30.1 & 76 & 82 \\
\hline & September & 18.1 & 3.9 & 16.8 & 23.5 & 88 & 88 \\
\hline & October & 13.2 & 10.5 & 26.9 & 36.1 & 67 & 74 \\
\hline & November & 4.1 & 3.9 & 16.8 & 30.1 & 76 & 82 \\
\hline & December & 2.9 & -0.9 & 11.4 & 23.5 & 88 & 88 \\
\hline \multirow[t]{9}{*}{2020} & January & 1.6 & -3.1 & 6.2 & 17.9 & 81 & 89 \\
\hline & February & 2.8 & -2.4 & 13.1 & 17.4 & 75 & 86 \\
\hline & March & 7.5 & 2.5 & 23.1 & 28.0 & 71 & 84 \\
\hline & April & 10.5 & 10.7 & 15.9 & 43.5 & 70 & 74 \\
\hline & May & 17.9 & 16.3 & 105.5 & 63.5 & 75 & 72 \\
\hline & June & 23.5 & 20.6 & 55.6 & 77.9 & 64 & 69 \\
\hline & July & 26.9 & 23.1 & 32.0 & 59.9 & 63 & 67 \\
\hline & August & 23.2 & 22.5 & 73.9 & 46.9 & 61 & 69 \\
\hline & September & 19.7 & 17.3 & 0 & 36.1 & 70.3 & 74 \\
\hline
\end{tabular}

\section{Results and discussion}

During the autumn of 2018 (from September to December inclusive), $51.2 \mathrm{~mm}$ of precipitation fell at a rate of $110.7 \mathrm{~mm}$, which did not even allow winter wheat to grow in autumn, despite the optimal planting time. The scarcity of soil moisture was apparently not enough for wheat seed germination and smooth and timely sprouts. No snow cover was formed and was observed for only 1-3 days. The sprouts emerged slowly from late January through February and developed poorly.

The yield of Cheget winter wheat in the option 1 - without fertilizer and irrigation (control) - after 69 years of the experiment averaged $18.6 \mathrm{dt} /$ ha (Table 2), and for three different predecessors: alfalfa, maize, sunflower, it was almost identical, which is statistically proven. 
Table 2. Crop yields and crop rotation productivity in the experience of 1948 in 2018, dt/ha.

\begin{tabular}{|c|c|c|c|c|c|c|}
\hline $\begin{array}{c}\text { Water } \\
\text { availability }\end{array}$ & Fertilizer options & $\begin{array}{l}\text { Cheget } \\
\text { winter } \\
\text { wheat }\end{array}$ & $\begin{array}{l}\text { Terek } \\
\text { maize }\end{array}$ & $\begin{array}{c}\text { SPK } \\
\text { sunflower }\end{array}$ & $\begin{array}{l}\text { Kevsala } \\
\text { alfalfa } \\
\text { two-year- } \\
\text { old }\end{array}$ & $\begin{array}{l}\text { Productivity } \\
1 \text { ha, dt.g.u. }\end{array}$ \\
\hline \multirow[t]{3}{*}{$\begin{array}{l}\text { Without } \\
\text { irrigation }\end{array}$} & $\begin{array}{l}\text { 1. Without } \\
\text { fertilizers }\end{array}$ & 18.6 & 21.9 & 10.9 & 31.6 & 17.4 \\
\hline & $\begin{array}{l}\text { 2. Recommended } \\
\text { mineral } \\
\text { fertilization system } \\
\mathrm{N}_{69} \mathrm{P}_{63} \mathrm{~K}_{45}\end{array}$ & 51.3 & 32.0 & 14.0 & 53.8 & 33.1 \\
\hline & $\begin{array}{l}\text { 3. Recommended } \\
\text { organo-mineral } \\
\text { fertilization system } \\
\text { manure } 8 \mathrm{t} / \mathrm{ha}+ \\
\mathrm{N}_{44} \mathrm{P}_{42} \mathrm{~K}_{24} \\
\end{array}$ & 58.4 & 36.7 & 15.6 & 64.6 & 38.0 \\
\hline \multirow{9}{*}{$\begin{array}{l}\text { Irrigation, } \\
75-80 \% \\
\text { minimum } \\
\text { moisture- } \\
\text { holding } \\
\text { capacity }\end{array}$} & $\begin{array}{l}\text { 4. Without } \\
\text { fertilizers }\end{array}$ & 20.0 & 29.6 & 10.7 & 60.8 & 23.1 \\
\hline & $\begin{array}{l}\text { 5. Recommended } \\
\text { mineral } \\
\text { fertilization } \\
\text { system } \\
\mathrm{N}_{69} \mathrm{P}_{63} \mathrm{~K}_{45} \\
\end{array}$ & 48.1 & 43.8 & 13.6 & 82.7 & 38.7 \\
\hline & $\begin{array}{l}\text { 6. Recommended } \\
\text { organo-mineral } \\
\text { fertilization system } \\
\text { manure } 8 \mathrm{t} / \mathrm{ha}+ \\
\mathrm{N}_{44} \mathrm{P}_{42} \mathrm{~K}_{24}\end{array}$ & 55.6 & 49.0 & 16.2 & 105.5 & 45.3 \\
\hline & $\begin{array}{l}\text { 7. Estimated } \\
\text { mineral } \\
\text { fertilization system } \\
\mathrm{N}_{141} \mathrm{P}_{68} \mathrm{~K}_{60} \\
\end{array}$ & 55.7 & 47.7 & 15.8 & 96.8 & 44.0 \\
\hline & $\begin{array}{l}\text { 8. Estimated } \\
\quad \text { organo- } \\
\text { mineral } \\
\text { fertilization system } \\
\text { manure } 15 \mathrm{t} / \mathrm{ha} \\
+\mathrm{N}_{87} \mathrm{P}_{36} \mathrm{~K}_{7} \\
\end{array}$ & 61.1 & 62.0 & 17.6 & 118.6 & 52.6 \\
\hline & $\begin{array}{l}\text { LCD } 05 \text { particular } \\
\text { differences }\end{array}$ & 2.64 & 4.10 & 2.60 & $2.82 / 4.40$ & \\
\hline & $\begin{array}{l}\mathrm{LCD} 05 \text { for } \\
\text { irrigation }\end{array}$ & 0.84 & 1.30 & 1.16 & $1.81 / 1.97$ & \\
\hline & $\begin{array}{l}\mathrm{LCD}_{05} \text { for } \\
\text { fertilizers and } \\
\text { interaction. }\end{array}$ & 1.07 & 1.44 & 1.84 & $2.28 / 3.10$ & \\
\hline & $\begin{array}{l}\text { Experiment } \\
\text { accuracy, } \mathrm{S}_{\mathrm{x}}, \%\end{array}$ & 3.46 & 3.69 & 6.40 & $2.95 / 1.85$ & \\
\hline
\end{tabular}

Recommended fertilization systems: mineral and organo-mineral in non-irrigated conditions (options 2 and 3), in 2018 provided, on average, a higher yield of Cheget winter wheat (51.3 and 58.4, respectively) than wheat yield in similar irrigated crop options (options 5 and 6) by 3.2-2.8 dt/ha, which is mathematically reliable, and is explained by the fact that soil fertility in dryland options is undoubtedly higher than in irrigated options, and the weather conditions favorable for winter wheat made it possible to realize the advantage of a higher humus and nutrient content in the root layer of the soil to produce a higher yield. 
The estimated fertilization systems in the irrigated crop rotation (options 7 and 8) provided an increase in crop yield compared to the recommended fertilization systems of 5.5$7.6 \mathrm{dt} / \mathrm{ha}$, which exceeded the LSD05 by 2.5-2.7 times.

The highest grain yield of Cheget winter wheat 60.0-63.2 dt/ha, depending on the predecessor, is obtained in option 8 on the estimated organo-mineral fertilization system aimed at reproduction of soil fertility. In 2018, a large yield of winter wheat in this option was achieved on the alfalfa predecessor, which is mathematically reliable (Table 2).

Not only weather conditions have contributed to this yield, but also better timely soil preparation, planting of crops in optimal time and compliance of other agricultural practices.

It was found that with an optimal combination of accompanying factors, the efficiency of the studied fertilization systems increased more than 2 times. Thus, in the dryland crop rotation in 2018, mineral and organo-mineral fertilization systems achieved crop rotation productivity of 33.1 and $38.0 \mathrm{dt.g.u} / \mathrm{ha}$ with an average of 40 years of research (1970-2016) - 32.1 and 34,4 dt.g.u/ha. At the same time, the productivity of crop rotation without fertilization and irrigation was equal to $17.4 \mathrm{dt} . \mathrm{g}$.u/ha with average productivity of dryland unfertilized crop rotation of $17.2 \mathrm{dt} . \mathrm{g} . \mathrm{u} / \mathrm{ha}$.

The climatic characteristics of the 2009 growing season were also unfavorable for the growth, development and production of all field crops. The sprouts emerged slowly from late January through February and developed poorly. From January to March 2019, precipitation fell only $58.1 \mathrm{~mm}$, which was also less than the long-term average annual amount $(63.3 \mathrm{~mm})$ with temperatures significantly exceeding long-term ones by 3-40C. From April to August, $208.6 \mathrm{~mm}$ of precipitation fell, with a norm of $291.7 \mathrm{~mm}$. Temperatures during the summer months were from 2.4 to $5.3 \mathrm{o}$ higher than the long-term average annual temperature, which contributed to the water scarcity for all crops. The relative air humidity in all months of growing season was less than the annual average by 2-14\%. June 2019 was particularly unfavorable for climatic characteristics (Table. 1).

Such changes in climatic characteristics indicate a tightening of dryland cultivation conditions in comparison with previous decades. Low precipitation and high air temperatures are not only responsible for soil and air drought, but also for reduced crop yields.

The yield of Cheget winter wheat in option 1, without fertilizer and irrigation, after 70 years of the experiment averaged $19.8 \mathrm{dt} / \mathrm{ha}$. In option 4, without fertilizers in irrigation, its average yield was $21.4 \mathrm{dt} /$ ha (Table 3 ). In the non-irrigated crop rotation of the experiment in 2019, the influence of predecessors on winter wheat yields: alfalfa, maize, sunflower, was almost the same, the changes in yield indicators for all studied fertilization systems did not exceed the smallest significant difference.

Recommended fertilization systems: mineral and organo-mineral in non-irrigated conditions (options 2 and 3) provided, on average, lower winter wheat yields in 2019 than wheat yields in similar irrigated crop options (options 5 and 6) by 0.7 and $2.1 \mathrm{dt} / \mathrm{ha}$, respectively, which is mathematically reliable (Table 3 ). Based on a comparative estimation of the soil fertility in these options under dryland and irrigated conditions, when the soil fertility in the dryland options, undoubtedly better, weather conditions unfavorable to winter wheat did not allow to realize the advantage of sufficient humus and nutrients in the root soil layer to produce a higher yield, since the decisive factor in its formation in an extremely dry year was the provision of plants with moisture.

The estimated fertilization systems in irrigated crop rotation, options 7 and 8, provided an increase in crop yield compared to the recommended fertilization systems of only 1.7-1.8 $\mathrm{dt} / \mathrm{ha}$, which exceeded the LCD05 for fertilizers by 2.3 times.

The highest grain yield of Cheget winter wheat is 38.7-39.2, i.e. 1.5 times less than in the previous year, depending on the predecessor, produced in option 8 on the estimated organomineral fertilization system aimed at reproduction of soil fertility. In 2019 the winter wheat 
yield in this option was almost the same for all studied predecessors, the difference in yield did not exceed the least significant difference for this factor (Table. 3 ).

Table 3. Crop yields (dt/ha) and productivity of 1 hectare of crop rotations in the experiment of 1948, 2019.

\begin{tabular}{|c|c|c|c|c|c|c|}
\hline $\begin{array}{c}\text { Water } \\
\text { availabilit } \\
y\end{array}$ & $\begin{array}{l}\text { Fertilizer } \\
\text { options }\end{array}$ & $\begin{array}{l}\text { Chege } \\
\text { t } \\
\text { winter } \\
\text { wheat }\end{array}$ & $\begin{array}{l}\text { Terek } \\
\text { maize }\end{array}$ & $\begin{array}{c}\text { SPK } \\
\text { sunflowe } \\
\mathbf{r}\end{array}$ & $\begin{array}{l}\text { Kevsala } \\
\text { alfalfa } \\
\text { two-year- } \\
\text { old }\end{array}$ & $\begin{array}{l}\text { Productivit } \\
\quad y \\
1 \text { ha, dt.g.u. }\end{array}$ \\
\hline \multirow[t]{3}{*}{$\begin{array}{l}\text { Without } \\
\text { irrigation }\end{array}$} & $\begin{array}{l}\text { 1. Without } \\
\text { fertilizers }\end{array}$ & 19.8 & 0 & 0 & $2.3 / 8.4$ & 6.5 \\
\hline & $\begin{array}{l}\text { Recommended } \\
\text { mineral } \\
\text { fertilization } \\
\text { system } \\
\mathrm{N}_{69} \mathrm{P}_{63} \mathrm{~K}_{45}\end{array}$ & 30.6 & 0 & 0 & $23.9 / 20.2$ & 11.4 \\
\hline & $\begin{array}{l}\text { 3.Recommended } \\
\text { organo-mineral } \\
\text { fertilization } \\
\text { system manure } 8 \\
\text { t/ha }+\mathrm{N}_{44} \mathrm{P}_{42} \mathrm{~K}_{24}\end{array}$ & 35.1 & 0 & 0 & $29.6 / 21.8$ & 13.1 \\
\hline \multirow{5}{*}{$\begin{array}{l}\text { Irrigation, } \\
75-80 \% \\
\text { minimum } \\
\text { moisture- } \\
\text { holding } \\
\text { capacity }\end{array}$} & $\begin{array}{l}1 \text { Without } \\
\text { fertilizers }\end{array}$ & 21.4 & 26.5 & 6.2 & $40.6 / 35.4$ & 19.6 \\
\hline & $\begin{array}{l}2 \text { Recommende } \\
\text { d mineral } \\
\text { fertilization } \\
\text { system } \\
\mathrm{N}_{69} \mathrm{P}_{63} \mathrm{~K}_{45}\end{array}$ & 31.3 & 36.7 & 12.9 & $70.0 / 79.5$ & 30.5 \\
\hline & $\begin{array}{l}3 \text { Recommende } \\
\text { d organo- } \\
\text { mineral } \\
\text { fertilization } \\
\text { system manure } 8 \\
\text { t/ha }+\mathrm{N}_{44} \mathrm{P}_{42} \mathrm{~K}_{24}\end{array}$ & 37.2 & 57.5 & 15.7 & $82.0 / 93.8$ & 36.6 \\
\hline & $\begin{array}{l}4 \text { Estimated } \\
\text { mineral } \\
\text { fertilization } \\
\text { system } \\
\mathrm{N}_{141} \mathrm{P}_{68} \mathrm{~K}_{60} \\
\end{array}$ & 33.0 & 40.2 & 13.7 & $\begin{array}{c}75.0 / 100 \\
9\end{array}$ & 33.6 \\
\hline & $\begin{array}{l}5 \text { Estimated } \\
\text { organo- } \\
\text { mineral } \\
\text { fertilization } \\
\text { system } \\
\text { manure } 15 \\
\mathrm{t} / \mathrm{ha}+\mathrm{N}_{87} \mathrm{P}_{36} \\
\mathrm{~K}_{7} \\
\end{array}$ & 39.0 & 64.8 & 18.5 & $\begin{array}{c}89.1 / 118 . \\
6\end{array}$ & 45.6 \\
\hline \multicolumn{2}{|c|}{$\mathrm{LCD}_{05}$ particular differences } & 1.82 & 2.27 & 1.04 & $1.99 / 4.40$ & \\
\hline \multicolumn{2}{|c|}{$\begin{array}{l}\mathrm{LCD}_{05} \text { for irrigation (maize- } \\
\text { predecessor) }\end{array}$} & 0.58 & $\begin{array}{c}\text { Not } \\
\text { substantiv } \\
\text { e }\end{array}$ & - & $0.96 / 1.97$ & \\
\hline \multicolumn{2}{|c|}{$\begin{array}{l}\mathrm{LCD}_{05} \text { for fertilizers and } \\
\text { interaction. }\end{array}$} & 0.74 & 1.14 & - & $1.41 / 3.10$ & \\
\hline \multicolumn{2}{|c|}{ Experiment accuracy, $\mathrm{S}_{\mathrm{x}}, \%$} & 2.03 & 1.75 & 1.94 & $1.31 / 3.39$ & \\
\hline
\end{tabular}


The importance of grain crop yields for crop rotation and crop rotation productivity in non-irrigated conditions in different years confirms their dependence on the amount of precipitation during the growing season and the year as a whole.

Without irrigation, the efficiency of the used fertilization systems is low. With the systematic use of the recommended mineral fertilizers N69P63K45 (option 2) to the crop rotation culture in 2019 , the crop rotation productivity was increased by 4.9 dt.g.u./ha to control or $75.4 \%$. The systematic use of the organo-mineral fertilization system (option 3), manure $8 \mathrm{t} / \mathrm{ha}+\mathrm{N} 44 \mathrm{P} 42 \mathrm{~K} 24$, provided the increase in the productivity of dryland crop rotation 6.6 dt.g.u/ha to control or $101.5 \%$.

The productivity of 1 hectare of crop rotation without fertilizers under irrigation (option 4) in 2019 was 19.6 dt.g.u. Irrigation increased the efficiency of the recommended mineral (option 5) and organo-mineral (option 6) fertilization systems and increased the annual average productivity of irrigated crop rotation by 55.6 and $86.7 \%$, respectively, compared to the option without fertilizers in irrigation, and 3.7 and 4.6 times compared to the control, without fertilizer or irrigation. The use of estimated fertilization systems, mineral and organo-mineral (to preserve and reproduce soil fertility and to obtain the productivity of irrigated crop rotation $52-53 \mathrm{dt} . \mathrm{g} . \mathrm{u} / \mathrm{ha}$ ) increased the productivity of 1 ha in irrigation by $71.4 \%$ and $132.7 \%$ respectively compared to the option 4 , without fertilizer in irrigation (Table 5) and 4.2 and 6.0 times compared to control.

In 2019, the productivity of crop rotation without irrigation was significantly (almost 3 times) less than the long-term average annual productivity.

In 2020, the research results also confirmed the dependence of crop yields and productivity of non-irrigated crop rotation, primarily on the amount of precipitation during the growing season and the year as a whole, and then on the conditions of mineral nutrition.

From January to March 2020, precipitation fell $42.4 \mathrm{~mm}$, which is $20.9 \mathrm{~mm}$ less than the long-term precipitation for the same period, at temperatures exceeding long-term ones. From April to August, $282.9 \mathrm{~mm}$ of precipitation fell, with a norm of $291.7 \mathrm{~mm}$. The temperatures during the summer months were 0.7-3.8o higher than the average long-term temperature, which contributed to the development of moisture deficiency for spring crops.

The yield of Yuzhanka winter wheat in 2020 with fertilization without irrigation was relatively high, as against the other crop rotations, which was achieved due to the biological characteristics of the crop and its ability to efficiently use of available soil moisture.

In option 1, without fertilizer or irrigation, after 71 years of the experiment (Table 4), yields averaged $18.2 \mathrm{dt} / \mathrm{ha}$ and for three different predecessors: alfalfa, maize, sunflower, it was almost the same, which is statistically proven. In option 4, without fertilizers in irrigation, its average yield was $19.1 \mathrm{dt} / \mathrm{ha}$.

Recommended fertilization system: mineral in non-irrigated conditions (option 2) in 2020, provided, on average, a lower yield of Yuzhanka winter wheat of $32.9 \mathrm{dt} / \mathrm{ha}$ than wheat yield in a same version of irrigated crop rotation (option $5-34.3 \mathrm{dt} / \mathrm{ha}$ ) by $1.4 \mathrm{dt} / \mathrm{ha}$. The estimated fertilization systems in irrigated crop rotation, options 7 and 8 (33.1 and $39.7 \mathrm{dt} / \mathrm{ha}$ ), provided an increase in crop yield compared to the recommended fertilization systems of 1.2$3.0 \mathrm{dt} / \mathrm{ha}$.

The highest yield of Yuzhanka winter wheat grain is 38.0-39.7 dt/ha, depending on the predecessor, produced in option 8 from the estimated organo-mineral fertilization system aimed at reproduction of soil fertility (Table 4). In 2020, high yield of winter wheat in this option was achieved by the maize predecessor, which is mathematically relevant. 
Table 4. Crop yields and crop rotation productivity in the experiment of 1948 in 2020, dt/ha.

\begin{tabular}{|c|c|c|c|c|c|c|}
\hline $\begin{array}{c}\text { Water } \\
\text { availabilit } \\
y\end{array}$ & Fertilizer options & $\begin{array}{c}\text { Yuzhank } \\
\text { a winter } \\
\text { wheat }\end{array}$ & $\begin{array}{c}\text { Kara } \\
\mathbf{t} \\
\text { maize }\end{array}$ & $\begin{array}{c}\text { SPK } \\
\text { sunflowe } \\
\mathbf{r}\end{array}$ & $\begin{array}{c}\text { Kevsala } \\
\text { alfalfa } \\
\text { two-year- } \\
\text { old }\end{array}$ & $\begin{array}{c}\text { Productivit } \\
y \\
1 \text { ha, dt.g.u. }\end{array}$ \\
\hline \multirow[t]{3}{*}{$\begin{array}{l}\text { Without } \\
\text { irrigation }\end{array}$} & $\begin{array}{l}\text { 1. Without } \\
\text { fertilizers }\end{array}$ & 18.2 & 0 & 0 & $30.8 / 30.5$ & 17.2 \\
\hline & $\begin{array}{l}\text { 2. Recommende } \\
\mathrm{d} \text { mineral } \\
\text { fertilization } \\
\text { system } \\
\mathrm{N}_{69} \mathrm{P}_{63} \mathrm{~K}_{45} \\
\end{array}$ & 32.9 & 0 & 0 & $46.3 / 55.9$ & 30.2 \\
\hline & $\begin{array}{l}\text { 3. Recommende } \\
\text { d organo- } \\
\text { mineral } \\
\text { fertilization } \\
\text { system } \\
\text { manure } 8 \mathrm{t} / \mathrm{ha} \\
+\mathrm{N}_{44} \mathrm{P}_{42} \mathrm{~K}_{2} \\
\end{array}$ & 31.8 & 0 & 0 & $53.9 / 67.9$ & 33.0 \\
\hline \multirow{9}{*}{$\begin{array}{l}\text { Irrigation, } \\
75-80 \% \\
\text { minimum } \\
\text { moisture- } \\
\text { holding } \\
\text { capacity }\end{array}$} & $\begin{array}{l}\text { 4. Without } \\
\text { fertilizers }\end{array}$ & 19.1 & 22.4 & 7.8 & $47.5 / 70.1$ & 19.9 \\
\hline & $\begin{array}{l}\text { 5. Recommende } \\
\text { d mineral } \\
\text { fertilization } \\
\text { system } \\
\mathrm{N}_{69} \mathrm{P}_{63} \mathrm{~K}_{45} \\
\end{array}$ & 34.3 & 29.9 & 10.2 & $71.3 / 85.1$ & 28.3 \\
\hline & $\begin{array}{l}\text { 6. Recommende } \\
\text { d organo- } \\
\text { mineral } \\
\text { fertilization } \\
\text { system } \\
\text { manure } 8 \mathrm{t} / \mathrm{ha} \\
+\mathrm{N}_{44} \mathrm{P}_{42} \mathrm{~K}_{24} \\
\end{array}$ & 36.7 & 40.1 & 16.2 & $\begin{array}{c}80.8 / 119 \\
2\end{array}$ & 36.2 \\
\hline & $\begin{array}{l}\text { 7. Estimated } \\
\text { mineral } \\
\text { fertilization } \\
\text { system } \\
\mathrm{N}_{141} \mathrm{P}_{68} \mathrm{~K}_{60} \\
\end{array}$ & 33.1 & 35.6 & 15.6 & $\begin{array}{c}77.0 / 108 \\
7\end{array}$ & 32.9 \\
\hline & 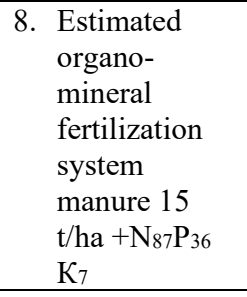 & 39.7 & 42.9 & 10.2 & $\begin{array}{c}85.5 / 142 \\
7\end{array}$ & 38.4 \\
\hline & $\begin{array}{l}\text { LCD } 05 \text { particular } \\
\text { differences }\end{array}$ & 1.89 & 3.47 & 1.31 & $2.82 / 4.40$ & \\
\hline & $\begin{array}{l}\mathrm{LCD}_{05} \text { for } \\
\text { irrigation }\end{array}$ & 0.59 & 2.65 & 0.59 & $1.81 / 1.97$ & \\
\hline & $\begin{array}{l}\text { LCD } 05 \text { for } \\
\text { fertilizers and } \\
\text { interaction. }\end{array}$ & 0.78 & 1.33 & 0.93 & $2.28 / 3.10$ & \\
\hline & $\begin{array}{l}\text { Experiment } \\
\text { accuracy, } \mathrm{S}_{\mathrm{x}}, \%\end{array}$ & 2.11 & 5.13 & 3.06 & $2.95 / 1.85$ & \\
\hline
\end{tabular}


The efficiency of the applied fertilization systems in non-irrigated conditions is low, especially in years with insufficient water availability. Thus, the efficiency of the applied fertilization systems in 2020 with the systematic use of recommended mineral fertilizers for crops $\left(\mathrm{N}_{69} \mathrm{P}_{63} \mathrm{~K}_{45}\right.$ on average for the year of rotation) was $13.0 \mathrm{dt}$.g.u./ha to control, or $75.5 \%$ higher. The systematic use of the organo-mineral fertilization system (option 3), manure 8 $\mathrm{t} / \mathrm{ha}+{ }_{44} \mathrm{P}_{42} \mathrm{~K}_{24}$, provided an increase the productivity of dryland crop rotation of 15.8 dt.g.u/ha to control or $91.8 \%$ higher.

The productivity of 1 hectare of crop rotation without fertilizer in irrigation (option 4) in 2020 was 19.9 dt.g.u/ha. Irrigation increased the efficiency of the recommended mineral (option 5) and organo-mineral (option 6) fertilization systems (28.3 and 36.2 dt.g.u/ha) (Table 5) and increased the average annual productivity of irrigated crop rotation in these options by 65 and $110 \%$, respectively, compared to the control (17.2 dt.g.u/ha).

The use of estimated fertilization systems, mineral and organo-mineral (options 7 and 8 32.9 and 38.4 dt.g.u./ha) In order to maintain and reproduce soil fertility and to increase the productivity of irrigated crop rotation, the productivity of 1 hectare in irrigation increased by $91 \%$ and $123 \%$, respectively.

\section{Conclusion}

1. As a result of scientific research in 2018-2020 it was identified that the efficiency of the use of different mineral and organo-mineral fertilization systems in conditions of natural humidification and irrigation on ordinary carbonate chernozem of the Central Ciscaucasia differed and depended largely on water availability and moisture reserves in the soil.

2. With an optimal combination of factors, the efficiency of the studied fertilization systems increased in dryland crop rotation by 1.8-2.2 times. Thus, in the dryland crop rotation, in 2018, the mineral and organo-mineral fertilization systems achieved crop rotation productivity of 33.1 and 38.0 , and in 2020 - 32.5 and 35.9 dt.g.u./ha, respectively, with average productivity over 40 years of the study (1970- 2016) - 32.1 and 34.4dt.g.u./ha. At the same time, the productivity of crop rotation without fertilizers and irrigation was 17.4 and 17.2dt.g.u./ha, respectively, while the average productivity of the dryland inconvenient crop rotation was $17.2 \mathrm{dt.g.u} / \mathrm{ha}$

3. Under unfavorable climatic characteristics, the efficiency of the studied fertilization systems has decreased more than 3 times. Thus, in the dryland crop rotation in 2019, with the use of mineral and organo-mineral fertilization systems, productivity of the crop rotation of 11.4 and 13.1 dt.g.u./ha was achieved with an average of 32.1 and 34.4 dt.g.u./ha in 40 years of research (1970-2016). At the same time, the productivity of crop rotation without fertilization and irrigation was only 6.5 dt.g.u./ha with average productivity of $17.2 \mathrm{dt} . \mathrm{g} . \mathrm{u}$. /ha.

4. The estimated fertilization systems in irrigated crop rotation, aimed at maintaining and reproducing soil fertility and increasing the productivity of irrigated crop rotation, have increased the productivity of irrigated crop rotation in comparison with recommended fertilization systems in different years by 2.2-9.0 dt.g.u./ha.

\section{References}

1. V. M. Novikov, Agriculture, 13 (2015)

2. V. M. Bizhoev, Agrochemistry, 37 (1988)

3. Guidelines for the Geographic Network of Fertilizer Experiments (1970) 
4. Guidelines for conducting research in long-term experiments with fertilizers, Experimental technique and soil analysis, 1 (1975)

5. Guidelines for conducting research in long-term experiments with fertilizers, Program and methods of soil research, 2 (1983)

6. B. A. Dospekhov, Field experiment methodology (with the basics of statistical processing of research results (1985)

7. F.A. Yudin, Agrochemical research technique, 11, 16, 100 (1971)

8. Methodological and organizational bases of conducting agoecological monitoring in intensive agriculture (1991) 